\title{
Intra-articular concentration of gentamicin administered by intravenous regional limb perfusion in healthy horses
}

\section{Renan Grigoletto ${ }^{1}$ (i) Renata Gebara Sampaio Dória ${ }^{1^{*}}$ (i) Gustavo Morandini Reginato ${ }^{1}$ (i) Pedro Henrique Salles Brito ${ }^{1}$ Marília Alves Ferreira ${ }^{1}$ Laís Grigoletto $^{1}{ }^{(1)}$ Felipe Rebello Lourenço ${ }^{2}$ (i) Daniele Martins dos Santos ${ }^{1}$ (1)}

'Faculdade de Zootecnia e Engenharia de Alimentos (FZEA), Universidade de São Paulo (USP), 13635-900, Pirassununga, SP, Brasil. E-mail: redoria@usp.br. "Corresponding author.

${ }^{2}$ Faculdade de Ciências Farmacêuticas, Universidade de São Paulo (USP), São Paulo, SP, Brasil.

ABSTRACT: Intravenous regional limb perfusion (IRLP) is an efficient method to treat horses with synovial infections. However, information on the dose, volume, and intervals of administration is lacking. The aim of this study was to evaluate the intra-articular concentration of gentamicin administered by IRLP in horses over $24 \mathrm{~h}$ post-administration and evaluate the influence of the total perfused volume. Twenty horses were assigned to two treatment groups. Gentamicin 60 group $(G 60, n=10)$ and Gentamicin 250 group $(G 250, n=10)$ received IRLP of $6.6 \mathrm{mg} / \mathrm{kg}$ of gentamicin diluted in Ringer's lactate for a total volume of $60 \mathrm{ml}$ (G60) and $250 \mathrm{ml}$ (G250), respectively. Synovial fluid harvests were performed in the metacarpophalangeal joint before (0) and 4, 8, 12,16, 20, and 24 hours after IRLP. Agar diffusion was the assay for measuring gentamicin concentrations. Four hours after IRLP, the intra-articular concentration of gentamicin was $47.58 \pm 49.21 \mu \mathrm{g} / \mathrm{ml}$ in $\mathrm{G} 60$ and $10.92 \pm 6.11 \mu \mathrm{g} / \mathrm{ml}$ in $\mathrm{G} 250$. During the $24 \mathrm{~h}$ of harvest, the intra-articular concentration of gentamicin remained above the minimum inhibitory concentration for horses (MIC; $2 \mu \mathrm{g} / \mathrm{ml}$ ) in both experimental groups. In G60, the concentration of gentamicin in synovial fuid reached the maximal concentration and remained 8 to 10-fold higher than the MIC (Cmax: 16 to $20 \mu \mathrm{g} / \mathrm{ml}$ ) during $12 \mathrm{~h}$ after IRLP. These findings support that IRLP with $6.6 \mathrm{mg} / \mathrm{kg}$ of gentamicin diluted to a volume of $60 \mathrm{ml}$ promotes intra-articular concentrations higher than 250 $\mathrm{ml}$, remaining above the MIC for $24 \mathrm{~h}$ and at the maximum concentration for $12 \mathrm{~h}$.

Key words: antimicrobial, concentration, equines, synovial fluid, tourniquet.

Concentração intra-articular de gentamicina administrada por perfusão regional intravenosa em membros de equinos sadios

\begin{abstract}
RESUMO: A perfusão regional intravenosa (PRI) em membros de equinos é um método comprovadamente eficiente para o tratamento de infecções sinoviais, porém ainda existem lacunas quanto à dose, volume e intervalos de administração a serem utilizados. Neste estudo, objetivou-se avaliar a concentração intra-articular da gentamicina administrada por PRI em equinos, ao longo de 24 horas pós-administração, bem como avaliar a influência do volume total perfundido. Vinte equinos foram distribuídos em dois grupos experimentais, Grupo Gentamicina 60 (G60) e Grupo Gentamicina 250 (G250), representados por 10 equinos em cada grupo que receberam, por PRI, 6,6 mg/kg de gentamicina diluída em Ringer lactato para um total de $60 \mathrm{ml}$ (G60) ou $250 \mathrm{ml}$ (G250). As colheitas de líquido sinovial foram realizadas, na articulação metacarpo-falangeana, antes do início do experimento e após 4, 8, 12,16, 20, e 24 horas. Difusão em ágar foi o método para doseamento

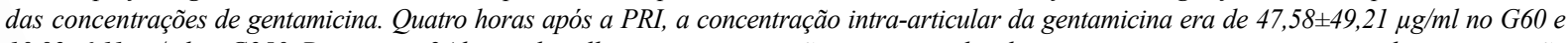
10,92 $\pm 6,11 \mu \mathrm{g} / \mathrm{ml}$ no G250. Durante as 24 horas de colheita, a concentração intra-articular de gentamicina permaneceu acima da concentração inibitória minima (CIM) $(2 \mu \mathrm{g} / \mathrm{ml})$ em ambos os grupos experimentais. No G60, as concentrações de gentamicina no líquido sinovial atingiram a concentração máxima e mantiveram-se 8 a 10 vezes mais elevadas que a CIM (Cmáx: 16 a $20 \mu \mathrm{g} / \mathrm{ml}$ ) durante 12 horas após a PRI. Concluise que a PRI em membros, com $6,6 \mathrm{mg} / \mathrm{kg}$ de gentamicina diluida para o volume de $60 \mathrm{ml}$, promove concentrações intra-articulares mais elevadas que o volume de $250 \mathrm{ml}$, permanecendo acima da CIM durante 24 horas e em concentração máxima durante 12 horas.

Palavras-chave: antimicrobianos, concentração, equinos, líquido sinovial, torniquete.
\end{abstract}

\section{INTRODUCTION}

Among the conditions that affect the joints of horses, septic arthritis is the most serious, which can result in rapid destruction of the articular cartilage and, when associated with osteomyelitis, irreversible loss of the articular surface can be a consequence (LLOYD et al., 1990; MORTON, 2005).

Antimicrobial drug administration through the systemic route may be considered ineffective for 
removal of infectious processes in the distal limbs of horses due to a low blood supply, that tends to get worse after installing an inflammatory process (WHITEHAIR et al., 1992a; MORTON, 2005; DORIA et al., 2015). The intravenous regional limb perfusion (IRLP) technique is an efficient method for the treatment of horses affected by synovial infections, which significantly reduces morbidity and mortality (BUTT et al., 2001; CIMETTI et al., 2004; RUBIO-MARTINEZ \& CRUZ, 2006).

The IRLP is a technique that consists of infusing a drug into a region of the organism that is vascularly isolated from the systemic circulation (SANTSCHI et al., 1998; RUBIO-MARTÍNEZ \& CRUZ, 2006). When the IRLP is performed with antibiotics, the high concentration of the drug, administered in a vein occluded by a tourniquet, generates a very high concentration gradient between the intravascular space and the tissues, which maximizes the diffusion process to all adjacent structures, especially those with little vascularity, such as cartilaginous tissue, ligaments and joint capsules, where pathogens are protected. The IRLP with antibiotics aims to increase the intra-articular concentration and the diffusion of the drug through the distal tissues of the affected limb of a horse, expanding the bactericidal effect, reducing the treatment time and minimizing adverse systemic effects (PARRA-SANCHEZ et al., 2006; RUBIOMARTÍNEZ \& CRUZ, 2006; ERRICO et al., 2008; GILLIAM et al., 2008).

Infectious musculoskeletal disorders in horses, such as septic arthritis, are often treated with aminoglycosides. Gentamicin is an effective antimicrobial against approximately $85 \%$ of the bacterial isolated in these cases and remains active in the synovial fluid (MOORE et al., 1992; COOK et al., 1999). The recommended dose of gentamicin for IRLP ranges from 125 to $1000 \mathrm{mg}$. In addition, it can be calculated based on the body weight of the animal using between a quarter of the dose up to the total systemic dose of $6.6 \mathrm{mg} / \mathrm{kg}$ (WHITEHAIR et al., 1992a, 1992b; WERNER et al., 2003; ERRICO et al., 2008).

There is a relationship between the final volume of the solution to be infused and the intravascular pressure that is achieved. RUBIOMARTÍNEZ \& CRUZ (2006) reported similarity between greater volume and higher intravascular pressure, yielding better diffusion to the adjacent tissues. However, it increases the risk of drug leakage through the tourniquet to the systemic circulation. In clinical practice, the calculated dose of the drug to be used is diluted in total volumes of 20 to $60 \mathrm{ml}$, depending on the region to be perfused. However, in the literature, the ideal volume is not known, as there is no exact number of regional perfusions to be performed (WHITEHAIR et al., 1992a, 1992b; MURPHEY et al., 1999; BUTT et al., 2001; SCHEUCH et al., 2002; MATTSON et al., 2004; ORSINI et al., 2004; ERRICO et al., 2008; KRAMER, 2006; PARRA-SANCHEZ et al., 2006; RUBIO-MARTINEZ \& CRUZ, 2006; ALKABES et al., 2011; RAFAEL, 2015).

Although considered a well-known and stablished technique (FINSTERBUSCH \& WEINBERG, 1972), IRLP lacks information regarding the dosage, volume, and intervals of administration. Therefore, the objective of the present study was to evaluate the intra-articular (IA) concentration of gentamicin, over $24 \mathrm{~h}$, after administration of $6.6 \mathrm{mg} / \mathrm{kg}$ of the drug, diluted to a volume of 60 and $250 \mathrm{ml}$, administered by IRLP.

\section{MATERIALS AND METHODS}

Twenty healthy adult horses, both males $(\mathrm{n}=5)$ and females $(\mathrm{n}=15)$, mixed breed, with an average weight of $360 \pm 50 \mathrm{~kg}$, were enrolled. During a previous experimental phase, the animals remained in $4 \times 4-m$ horse stalls, maintained on a Coast-cross hay-based diet ( $2 \%$ of body weight), pelleted horse feed ( $1 \%$ of body weight), mineral supplementation and water ad libitum, for adaptation and conditioning to the experiment routine.

Ten horses were assigned to each experimental group: Gentamicin 60 group (G60), in which animals received, by IRLP, $6.6 \mathrm{mg} / \mathrm{kg}$ of $10 \%$ gentamicin diluted in lactated Ringer solution for a total volume of $60 \mathrm{ml}$; and Gentamicin 250 group (G250), in which animals received, by IRLP, 6.6 $\mathrm{mg} / \mathrm{kg}$ of $10 \%$ gentamicin diluted in lactated Ringer solution for a total volume of $250 \mathrm{ml}$.

On experiment day 1, the animals were placed in a stock inside a specific room at 23 ${ }^{\circ} \mathrm{C}$ to facilitate the management of horses. They were sedated with $10 \%$ detomidine hydrochloride administered at a dose of $0.01 \mathrm{mg} / \mathrm{kg}$ intravenously. After clip and scrub, using soap and alcoholic chlorhexidine, the medial palmar vein of the right thoracic limb was cannulated in the proximal third of the metacarpal bone with a 22-G catheter connected to a PRN-type adapter. Subsequently, an Esmarch tourniquet was positioned above the catheter, in the distal third of the radius. The application of the tourniquet was standardized in 10 turns, in a clockwise 
direction, followed by fixation of the final portion of the Esmarch bandage (Figure 1). The tourniquet was always applied by the same researcher.

Subsequently, solutions were administered, with the aid of a scalp $\mathrm{n}^{\circ} 21$ and a $60 \mathrm{ml}$ syringe, for the animals of the $\mathrm{G} 60$ or a macrodrip and a $250 \mathrm{ml}$ lactate Ringer bag, for the animals of the G250. The infusion rate was standardized in 5 min for G60 and in $10 \mathrm{~min}$ for G250. The tourniquet was maintained for $40 \mathrm{~min}$ in both experimental groups. At the end of this period, the Esmarch tourniquet was released at once, and catheter was subsequently removed. The animals were observed for 7 days, and changes that indicated local reactions to IRLP, such as edema, increased limb temperature, and presence of a wound at the catheter insertion site, were noted.

Samples of synovial fluid were collected before beginning the experiment (T0) and in the sequential periods: 4 (T4), 8 (T8), 12 (T12), 16 (T16), 20 (T20), and 24 (T24) h after the IRLP. The antisepsis protocol (i.e., clipping and soap and

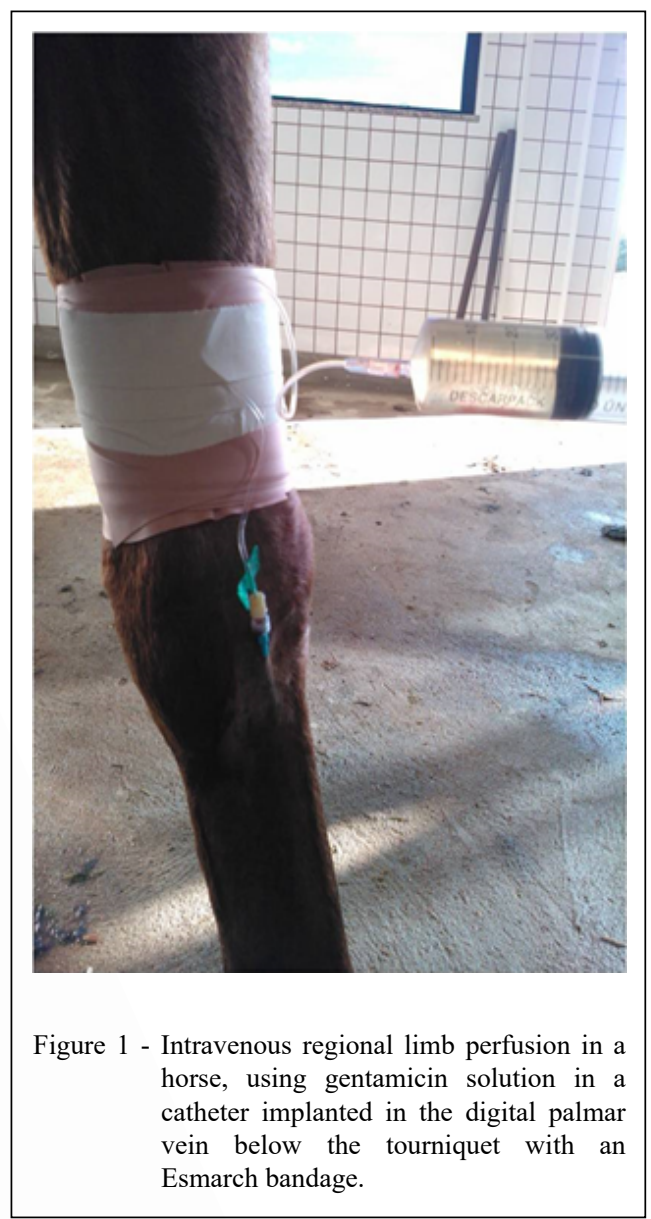

alcoholic chlorhexidine scrubbing) was applied before collecting the synovial fluid from the right metacarpal phalangeal joint. A 22-G catheter was introduced through the lateral collateral sesamoid ligament. After accessing the joint, a 3-ml syringe was attached to the needle, and $0.5 \mathrm{ml}$ of synovial fluid was gently aspirated. The synovial fluid was stored in a sterile cryotube and kept in a freezer $-80{ }^{\circ} \mathrm{C}$ for further analysis of the concentration of gentamicin in the synovial fluid using the agar gel diffusion technique (LOURENÇO \& PINTO, 2009).

For the microbiological assay of gentamicin, 6-mm-diameter paper discs (Schleicher and $S$ chuell ${ }^{\mathbb{}}$ ), previously immersed in standard solutions or samples were distributed in a $5 \times 1$ design (Figure 2). Each plate includes two doses, in alternating positions. On all plates one of the concentrations was the reference, which corresponds to the central concentration of the standard curve. The other was one of the four concentrations of the standard or sample dose of unknown potency, nominal dose equivalent to the standard reference. Microorganism test used as background was Staphylococcus epidermidis ATCC 12228, supplied by Adolfo Lutz Institute and Oswaldo Cruz Foundation. Cultures were maintained on an inclined surface of the antibiotic medium (number 11) by Difco or Oxoid. A culture of no more than $24 \mathrm{~h}$, incubated at a temperature of $32{ }^{\circ} \mathrm{C}-35$ ${ }^{\circ} \mathrm{C}$, was re-suspended in approximately $3 \mathrm{ml}$ of sterile saline. Successive dilutions were performed until a transmittance of $25 \% \pm 2 \%$ at $580 \mathrm{~nm}$ was obtained using a sterile saline solution as a blank. This suspension was used as the inoculum.

Plates were prepared by adding $21 \mathrm{ml}$ of an antibiotic medium (number 11) diluted in a buffer solution to the Petri dishes kept in a room with controlled temperature. After solidification of the base layer, an additional $4 \mathrm{ml}$ of antibiotic medium number 11 inoculated in a proportion of $1 \%$ was added. The plates were then incubated in a Nova Ética incubator (Mod. $411 \mathrm{D}$ ) for 16 to $18 \mathrm{~h}$ at a temperature of 37 ${ }^{\circ} \mathrm{C} \pm 1{ }^{\circ} \mathrm{C}$. Biological response was measured based on the diameters of the inhibition halos measured in $\mathrm{mm}$ using the Haloes caliper ${ }^{\circledR}$ halo reading device (Figure 2 ). Results were recorded and calculated according to the experimental design described by HEWITT (1977). To guarantee the validity of the assay, each standard curve was evaluated through the analysis of variance (ANOVA) for linearity and regression.

Gentamicin concentrations were compared over time between G60 and G250 using a oneway ANOVA test and Tukey post-hoc test using $\mathrm{R}$ software (R Project, 2018). Data values were 


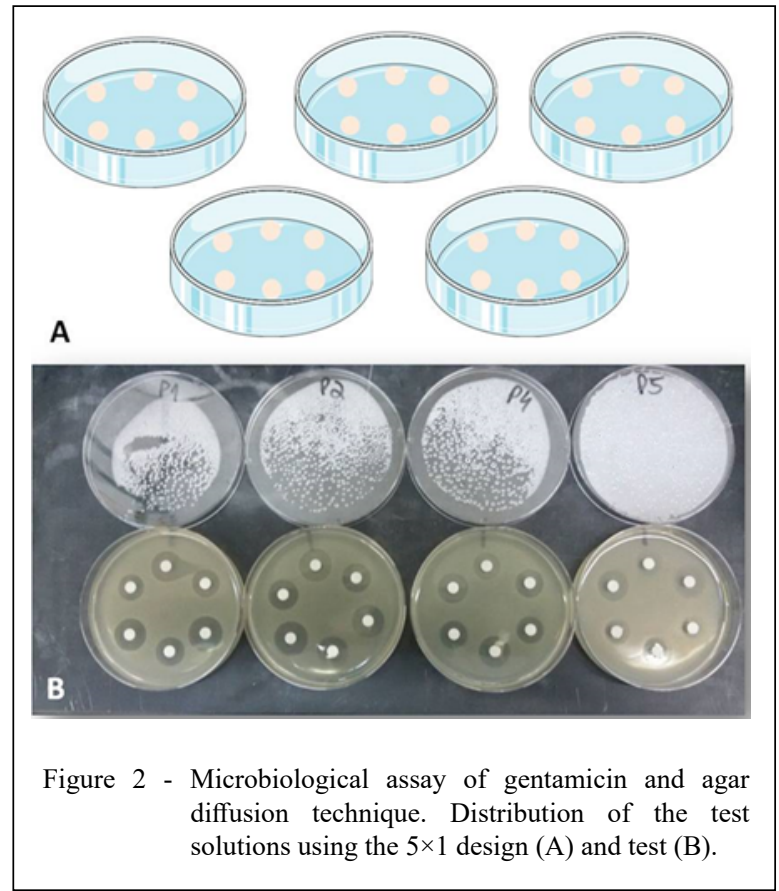

normally distributed following the Shapiro-Wilk test. Results are expressed as mean $\pm \mathrm{SD}$. The significance of all tests was set at $P \leq 0.05$.

\section{RESULTS}

There was no evidence of local adverse reactions to the administration of the drug by IRLP, such as edema, increased limb temperature or wound at the catheter insertion point, in none of the experimental animals. The microbiological assay of gentamicin was considered valid, showing an accuracy of 0.98 and a precision of $5.4 \%$. A progressive decrease in the IA gentamicin concentration was observed over 24 hours in both experimental groups (Figure 3 ).

The peak concentration of IA gentamicin was measured $4 \mathrm{~h}$ (T4) after IRLP in G60 $(47.58 \pm 49.21 \mu \mathrm{g} / \mathrm{ml})$. Regarding to T4, IA gentamicin concentration remained at lower values, after 8 , 12, 16, 20 and 24 hours. Therefore, the mean IA gentamicin concentration at T24 was $6.80 \pm 3.19 \mu \mathrm{g} / \mathrm{ml}$ in G60. The highest IA concentration of gentamicin in G250 was identified at T4 $(10.92 \pm 6.11 \mu \mathrm{g} / \mathrm{ml})$ and T8 $(8.10 \pm 3.47 \mu \mathrm{g} / \mathrm{ml})$; thus, there was no significant difference between T4 and T8. Regarding to T4 and T8, IA gentamicin remained at lower concentrations, after 12, 16, 20 and 24 hours. The mean concentration of IA gentamicin after $24 \mathrm{~h}$ in G250 was $3.85 \pm 2.17 \mu \mathrm{g} /$ $\mathrm{ml}$. G60 showed higher IA gentamicin concentrations distributed by the period measured compared to G250. There was a significant difference between G60 and G250 related to gentamicin concentration $(P \leq 0.05)$, as shown in table 1 . In addition, within each group, significant differences were observed in the experimental periods.

\section{DISCUSSION}

Gentamicin is an aminoglycoside antibiotic widely used in the infectious orthopedic treatment of horses as a concentration-dependent bactericidal agent (LLOYD et al., 1990; WERNER et al., 2003). This study showed that the intravenous regional limb perfusion method used was safe and effective, since after four hours, the intra-articular concentration of gentamicin was $47.58 \pm 49.21 \mu \mathrm{g} / \mathrm{ml}$ in G60 and $10.92 \pm 6,11 \mu \mathrm{g} / \mathrm{ml}$ in $\mathrm{G} 250$. The concentration of IA gentamicin remained above the minimum inhibitory concentration (MIC) of gentamicin, for horse's main orthopedics common pathogens $(2 \mu \mathrm{g} / \mathrm{ml}$ ) (MOORE et al., 1987; LLOYD et al., 1990; SKOPNIK et al., 1992; DURHAM, 2018), for over $24 \mathrm{~h}$, in both experimental groups, without local adverse effects.

The infusion of solutions by means of intravenous regional perfusion provides vascular distension in the limb region isolated by the tourniquet, creating high pressure and concentration gradients between the intravascular and extravascular spaces 


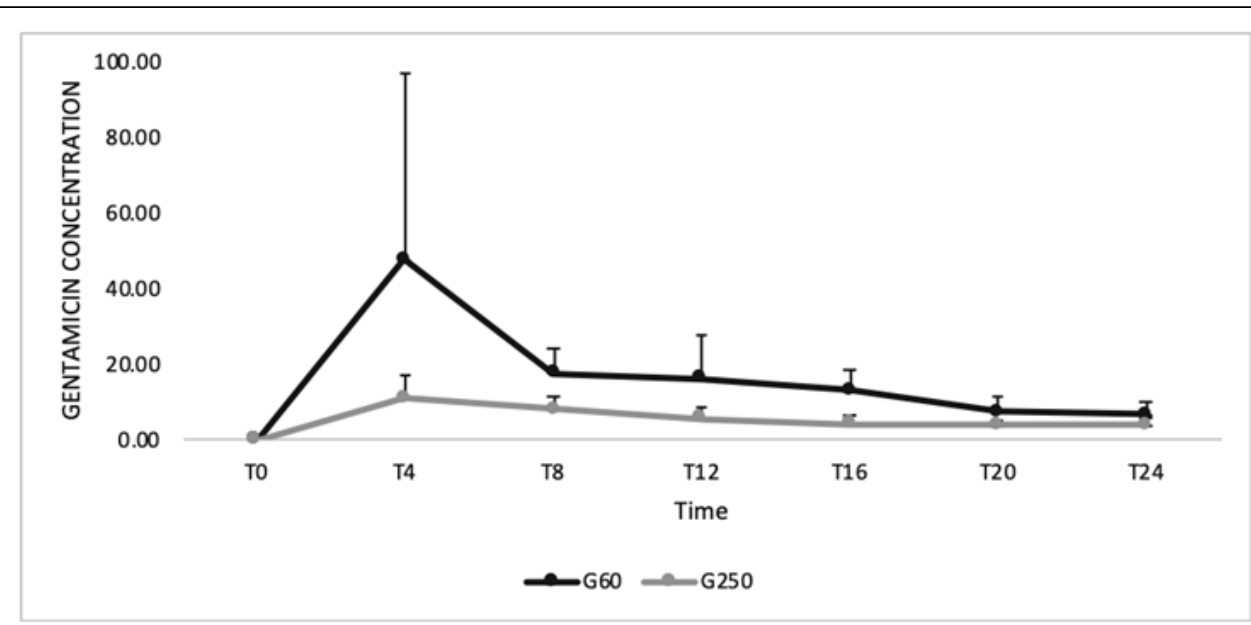

Figure 3 - Synovial fluid gentamicin concentration (mean value \pm standard deviation) in groups G60 and G250.

(SANTSCHI et al., 1998; RUBIO-MARTINEZ \& CRUZ, 2006). Hydrophilic drugs, such as gentamicin, are freely distributed by the interstitial fluid, presenting wide diffusion from intravascular to extravascular space, modulated by concentration gradient (NIX et al., 1991; RAFAEL, 2015). On the other hand, once the tourniquet is removed, the concentration gradients are inverted. As soon as the systemic circulation dilutes the high concentration of the antibiotic present in the extravascular space of the limb, the drug diffuses into the intravascular space and is removed from the region, resulting in a rapid decline in the concentration of antibiotics in tissues (NIX et al., 1991; EDWARDS, 2011; KELMER et al., 2012). However, as demonstrated in this study, intra-articular concentrations remain high, since, after the drug reaches the synovial fluid, its elimination is conditioned to joint metabolism. Notably, four hours (T4; G60 and G250) after IRLP, the mean IA concentration of gentamicin remained high, at 24 (G60) or 5 times (G250) above the MIC. Furthermore, after the 24-h period, the average intraarticular concentration of gentamicin remained 3.4 (G60) or 1.9 times (G250) above the MIC.

For the control of joint infections, through systemic administration of antibiotics, high serum concentrations are necessary to achieve the minimum inhibitory concentration in the intra-articular space, so that systemic administration may be not effective (LLOYD et al., 1990; NIX et al., 1991; MORTON, 2005). DÓRIA et al. (2015) demonstrated that systemic administration of gentamicin intravenously

Table 1 - Gentamicin concentration (mean value \pm standard deviation; $\mu \mathrm{g} / \mathrm{ml}$ ) in the synovial fluid of horses treated with intravenous regional limb perfusion of gentamicin $(6.6 \mathrm{mg} / \mathrm{kg})$, diluted to $60(\mathrm{G} 60)$ or $250 \mathrm{ml}(\mathrm{G} 250)$.

\begin{tabular}{lcr}
\hline Tempo & G60 & G250 \\
\hline T0 & $0.00^{\mathrm{a}}$ & $0.00^{\mathrm{a}}$ \\
T4 & $47.58 \pm 49.21^{\mathrm{b}^{*}}$ & $10.92 \pm 6.11^{\mathrm{b}^{*}}$ \\
T8 & $17.55 \pm 6.77^{\mathrm{c}^{*}}$ & $8.10 \pm 3.47^{\mathrm{b}^{*}}$ \\
T12 & $16.39 \pm 11.11^{\mathrm{d}^{*}}$ & $5.74 \pm 3.02^{\mathrm{c}^{*}}$ \\
T16 & $12.97 \pm 5.56^{\mathrm{d}^{*}}$ & $4.36 \pm 2.02^{\mathrm{c}^{*}}$ \\
T20 & $7.39 \pm 3.88^{\mathrm{e}^{*}}$ & $3.74 \pm 1.60^{\mathrm{c}^{*}}$ \\
T24 & $6.80 \pm 3.19^{\mathrm{e}^{*}}$ & $3.85 \pm 2.17^{\mathrm{c}^{*}}$ \\
\hline
\end{tabular}

Different letters represent difference between times within the group. ${ }^{*}$ represents difference between groups at the same time. $\mathrm{P} \leq 0.05$.

Ciência Rural, v.50, n.11, 2020. 
at a dose of $6.6 \mathrm{mg} / \mathrm{kg}$, for seven consecutive days, reached articular concentrations lower than MIC for horses. In this study, the same dose, administered by IRLP, reached intra-articular concentrations of $47.58 \pm 49.21 \mu \mathrm{g} / \mathrm{ml}$ (G60), three hours and 20 minutes after removal of the tourniquet, which corroborates with other studies (WHITEHAIR et al., 1992a; WHITEHAIR et al., 1992b; WERNER et al., 2003; RUBIO-MARTINEZ, 2012), demonstrating the superiority of this technique. It is important to highlight that the high value of standard deviation was due to one animal that could be considered an outlier; however, this particular animal represented an optimal response to drug administration.

The results of this study indicated that using a volume of $60 \mathrm{ml}$ to dilute the drug promotes a higher IA concentration measured over the experimental periods than $250 \mathrm{ml}$. This finding corroborates with other studies that used the drug in other dilutions and suggest that diffusion through a concentration gradient may be equally or even more important than venous distension (pressure gradient). Thus, the concentration of the solute influences the diffusion of the drug into the synovial fluid; and consequently, the intra-articular concentrations. In addition, venous distension created by excess volume can promote an increase in venous pressure, which exceeds the effective capacity of the tourniquet, resulting in a probable loss of the drug to the circulation (WHITEHAIR et al., 1992a; GAGNON et al., 1994; MURPHEY et al., 1999; SCHEUCH et al., 2002; PARRA-SANCHEZ et al., 2006; ERRICO et al., 2008; ALKABES et al., 2011; HYDE et al., 2013).

To our knowledge, there is no evidence related to an exact number of IRLP to be performed to treat infections in limbs of horses. In practice, IRLP is usually performed every 24,48 or 72 hours; however, the number of necessary perfusion sessions is dependent on the evolution of the case for each animal (BUTT et al., 2001; RUBIO-MARTÍNEZ and CRUZ, 2006).

Nevertheless, other parameters need to be accounted for in the therapeutic success of aminoglycoside antibiotics, such as drug maximum concentration (Cmax), which is 8 to 10 times higher than the MIC (DEZIEL-EVANS et al., 1986; DURHAM, 2018). This is more important than the time it remains at concentrations above MIC. The higher the Cmax, the greater bactericidal activity the aminoglycoside will present, also increasing its post-antibiotic power to inhibit bacterial growth (SKOPNIK et al., 1992, LACY et al., 1998).

The bactericidal activity of gentamicin, a concentration- or dose-dependent antimicrobial, is directly related to its serum peak. In summary, the bactericidal activity will be faster and greater when the concentration of the drug is higher. Furthermore, showing important residual bacteriostatic activity, which reflects the maintenance of suppression of bacterial growth even when drug concentrations are already below MIC (MOORE et al., 1987; LLOYD et al., 1990; NIX et al., 1991; SKOPNIK et al., 1992; MORTON, 2005; DURHAM, 2018). Thus, in this study, the average concentrations of gentamicin in the synovial fluid, at a dose of $6.6 \mathrm{mg} / \mathrm{kg}$, diluted in $60 \mathrm{ml}$, remained above $16-20 \mu \mathrm{g} / \mathrm{ml}$, for $12 \mathrm{~h}$ after IRLP, promoting greater bactericidal activity, differing from what was observed when the drug was diluted in $250 \mathrm{ml}$, which presented lower values already at $\mathrm{T} 4$.

This study shows that, when the systemic dose of gentamicin diluted in $60 \mathrm{ml}$ is used, the intra-articular concentration of the drug remains, for 24 hours, above MIC and 12 hours in Cmax, which provides an important bactericidal effect and residual bacteriostatic effect. The indication for frequency of repetition of IRLP, every 12 hours, in order to keep the intra-articular concentration of gentamicin constant, above the MIC or in Cmax, faces the question about adaptive resistance, that is, the reversible refractoriness for the bactericidal action of an antibacterial agent, in relation to the action of aminoglycosides against Gram-negative bacilli and, in particular, Pseudomonas aeruginosa (DAIKOS et al., 1990; BARCLAY et al., 1992; KARLOWSKY, et al., 1997; BARCLAY \& BEGG, 2001). Although poorly understood and discussed, this may be the most important characteristic of aminoglycosides to provide greater efficacy, with prolonged dose intervals, since the maintenance of continuous levels of the antimicrobial may be of little importance or even harmful (BARCLAY \& BEGG, 2001).

\section{CONCLUSION}

Intravenous regional limb perfusion in horses with $6.6 \mathrm{mg} / \mathrm{kg}$ of gentamicin, diluted to a total volume of $60 \mathrm{ml}$, promoted higher gentamicin intraarticular concentrations than the total volume of 250 $\mathrm{ml}$, remaining above the MIC for 24 hours and at the maximum concentration for 12 hours.

\section{BIOETHICS AND BIOSSECURITY COMMITTEE APPROVAL}

Ethical committee approval was obtained from the Animal Use Ethics Committee (CEAU-FZEA; Number: 13.1.2181.74.0). 


\section{ACKNOWLEDGEMENTS}

The authors acknowledge all scientific collaborations and the Laboratory of the Faculty of Pharmaceutical Sciences (FCF/USP), the National Council for Scientific and Technological Development (CNPq) - process $n^{\circ} 449297 / 2014-4$, and the Coordenação de Aperfeiçoamento de Pessoal de Nível Superior (CAPES), Brasil - Finance code 001.

\section{DECLARATION OF CONFLICT OF INTERESTS}

The authors declare no conflict of interest. The founding sponsors had no role in the design of the study; in the collection, analyses, or interpretation of data; in the writing of the manuscript, and in the decision to publish the results.

\section{AUTHORS' CONTRIBUTIONS}

All authors contributed equally to the conception and writing of the manuscript.

\section{REFERENCES}

ALKABES, S. B. et al. Comparison of two tourniquets and determination of amikacin sulfate concentrations after metacarpophalangeal joint lavage performed simultaneously with intravenous regional limb perfusion in horses. American Journal of Veterinary Research. v.72, p.613-619, 2011. Available from: $<$ https://avmajournals.avma.org/doi/abs/10.2460/ajvr.72.5.613 $>$. Accessed: Jun. 24, 2019. doi: 10.2460/ajvr.72.5.613.

BARCLAY, M. L.; BEGG, E. J. Aminoglycoside adaptive resistance importance for effective dosage regimens. Drugs. v.61, p.713-72, 2001. Available from: <https://link.springer.com/article /10.2165\%2F00003495-200161060-00001>. Accessed: Feb. 17 , 2020. doi: 10.2165/00003495-200161060-00001.

BARCLAY, M. L. et al. Adaptive resistance following single doses of gentamicin in a dynamic in vitro model. Antimicrobial Agent and Chemotherapy. v.36, p.1951-1957, 1992. Available from: $<$ https://aac.asm.org/content/36/9/1951>. Accessed: Feb. 17, 2020. doi: 10.1128/AAC.36.9.1951

BUTT, T. D. et al. Comparison of 2 techniques for regional antibiotic delivery to the equine forelimb: intraosseous perfusion vs. intravenous perfusion. Canadian Veterinary Journal. v.42, p.617-622, 2001. Available from: <https://www. ncbi.nlm.nih.gov/pmc/articles/PMC1476572/>. Accessed: Jun. 24, 2019. PMC: 1476572.

CIMETTI, L. J. et al. How to perform intravenous regional limb perfusion using amikacin and DMSO. 50th Annual Convention of the American Association of Equine Practitioners. Ithaca, New York, p.219-223, 2004. Available from: <http://www ssequineclinic.com/downloads/articles_IRLP.pdf $>$. Accessed: Jun. 24, 2019.

COOK, V. L. et al. Biodegradable drug delivery systems for gentamicin release and treatment of synovial membrane infection. Veterinary Surgery. v.28, p.233-241, 1999. Available from: $<$ https://doi.org/10.1053/jvet.1999.0233>. Accessed: Feb. 17, 2020. doi: $10.1053 /$ jvet.1999.0233
DAIKOS, G. L. et al. Adaptive resistance to aminoglycoside antibiotics from first-exposure down-regulation. The Journal of Infectious Diseases. v.162, p.414-420, 1990. Available from: <https://doi.org/10.1093/infdis/162.2.414>. Accessed: Feb. 17, 2020. doi: 10.1093/infdis/162.2.414

DEZIEL-EVANS, L. M. et al. Correlation of pharmacokinetic indices with therapeutic outcome in patients receiving aminoglycosides. Clinical Pharmacology. v.5, p.319-324, 1986.

DÓRIA, R. G. S. et al. Comparação da concentração plasmática e intra-articular de gentamicina administrada por via intravenosa em equinos. 16 $^{\circ}$ Conferência Anual ABRAVEQ, Águas de Lindóia, São Paulo, 2015.

DURHAM, A. E. An evaluation of serum gentamicin concentrations and bacterial susceptibility to gentamicin in equine practice. Journal of Veterinary Internal Medicine. v.32, p.1194-1201, 2018. Available from: <https://onlinelibrary.wiley.com/doi/full/10.1111/jvim.15078>. Accessed: Jun. 24, 2019. doi: 10.1111/jvim.15078.

EDWARDS, S. H. R. Intra-articular drug delivery: the challenge to extend drug residence time within the joint. Veterinary Journal. v.190, p.15-21, 2011. Available from: <https://www.sciencedirect. com/science/article/pii/S1090023310003102?via\%3Dihub>. Accessed: Jun. 24, 2019. doi: 10.1016/j.tvj1.2010.09.019.

ERRICO, J.A. et al. Comparison of two indirect techniques for local delivery of a high dose of an antimicrobial in the distal portion of forelimbs of horses. American Journal of Veterinary Research. v.69, p.334-342, 2008. Available from: <https://avmajournals. avma.org/doi/abs/10.2460/ajvr.69.3.334>. Accessed: Jun. 24, 2019. doi: 10.2460/ajvr.69.3.334.

FINSTERBUSCH, A.; WEINBERG $H$. Venous perfusion of the limb with antibiotics for osteomyelitis and other chronic infections. Journal of Bone Joint Surgery. v.54, p.12271234, 1972. Available from: <https://www.ncbi.nlm.nih.gov/ pubmed/4652053>. Accessed: Jun. 24, 2019. pmid: 4652053.

GAGNON, H. et al. Single-dose pharmacokinetics of cefazolin in bovine synovial fluid after intravenous regional injection. Journal of Veterinary Pharmacology and Therapeutics. v.17, p.31-37, 1994. Available from: <https://doi.org/10.1111/j.1365-2885.1994. tb00518.x>. Accessed: Jun. 24, 2019. doi: 10.1111/j.13652885.1994.tb00518.x.

GILLIAM, J. N. et al. Pharmacokinetics of florfenicol in serum and synovial fluid after regional intravenous perfusion in the distal portion of the hind limb of adult cows. American Journal of Veterinary Research. v.69, p.997-1004, 2008. Available from: $<$ https://avmajournals.avma.org/doi/abs/10.2460/ajvr.69.8.997>. Accessed: Jun. 24, 2019. doi: 10.2460/ajvr.69.8.997.

HEWITT, W. Microbiologycal Assay. 1st ed. Academic Press, Orlando, 1977. 298 p

HYDE, M. R. et al. The influence of perfusate volume on antimicrobial concentration in synovial fluid following intravenous regional limb perfusion in the standing horse. Canadian Veterinary Journal. v.54, p.363-367, 2013. Available from: <https://www. ncbi.nlm.nih.gov/pmc/articles/PMC3595939/>. Accessed: Jun. 24, 2019. pmid: 24082163.

KARLOWSKY, J. A. et al. Aminoglycoside adaptive resistance. Pharmacotherapy. v.17, n.3, p.549-555, 1997. Available from: 
<https://doi.org/10.1002/j.1875-9114.1997.tb03063.x>. Accessed: Feb. 17, 2020. PMID: 9165557.

KELMER, G. et al. Indwelling cephalic or saphenous vein catheter use for regional limb perfusion in 44 horses with synovial injury involving the distal aspect of the limb. Veterinary Surgery. v.241, p.1650-1658, 2012. Available from: <https://doi.org/10.1111/ j.1532-950X.2012.01006.x>. Accessed: Jun. 24, 2019. doi: 10.1111/j.1532-950X.2012.01006.X.

LACY, M.K. et al. The pharmacodynamics of aminoglycosides. Clinical Infectious Disease. v.27, p.23-27, 1998. Available from: $<$ https://doi.org/10.1086/514620>. Accessed: Feb. 17, 2020. PMID: 9675444.

LLOYD, K. C. C. et al. Plasma and synovial fluid, concentration of gentamicin after intra-articular administration of drug in experimental model of infectious arthritis in horses. Journal of American Veterinary Medical Association. v.51, p.13631369, 1990. Available from: <https://doi.org/10.1111/j.1532950X.2003.00559.x>. Accessed: Jun. 24, 2019. doi: 10.1111/j.1532950X.2003.00559.x.

LOURENCO, F. R.; PINTO T. J. A. Comparison of three experimental designs employed in gentamicin microbiological assay through agar diffusion. Brazilian Journal of Pharmaceutical Sciences. v.45, p.559-566, 2009. Available from: <http://dx.doi. org/10.1590/S1984-82502009000300022>. Accessed: Jun. 24, 2019. doi: 10.1590/S1984-82502009000300022.

MOORE, R. D. et al. Clinical response to aminoglycoside therapy: importance of the ratio of peak concentration to minimal inhibitory concentration. Journal of Infectious Diseases. v.155, p.93-99, 1987. Available from: <https://doi.org/10.1093/infdis/155.1.93>. Accessed: Jun. 24, 2019. doi: 10.1093/infdis/155.1.93.

MOORE, R. M. et al. Antimicrobial susceptibility of bacterial isolates from 233 horses with musculoskeletal infection during 1979-1989. Equine Veterinary Journal. v.24, p.450-456, 1992. Available from: $<$ https://doi.org/10.1111/j.2042-3306.1992.tb02875.x>. Accessed: Feb. 17, 2020. doi: 10.1111/j.2042-3306.1992.tb02875.x

MORTON, A. J. Diagnosis and treatment of septic arthritis. Veterinary Clinics of North American Equine Practice. v.21, p.627-649, 2005. Available from: <https://doi.org/10.1016/j. cveq.2005.08.001>. Accessed: Jun. 24, 2019. doi: 10.1016/j. cveq.2005.08.001.

MURPHEY, E. D. et al. Regional intravenous perfusion of the distal limb of horses with amikacin sulfate. Journal of Veterinary Pharmacology and Therapeutics. v.22, p.68-77, 1999. Available from: $\quad<$ https://doi.org/10.1046/j.1365-2885.1999.00180.x $>$. Accessed: Jun. 24, 2019. doi: 10.1046/j.1365-2885.1999.00180.x.

NIX, D.E. et al. Antibiotic Tissue Penetration and its Relevance: Models of Tissue Penetration and Their Meaning. Antimicrobial Agents Chemotherapy. v.35, p.1947-1952, 1991. Available from: $<$ https://aac.asm.org/content/aac/35/10/1947.full.pdf>. Accessed: Jun. 24, 2019. doi: 10.1128/AAC.35.10.1947.

PARRA-SANCHEZ, A. et al. Pharmacokinetics and pharmacodynamics of enrofloxacin and low dose of amikacin administered via regional intravenous limb perfusion in standing horses. American Journal of Veterinary Research. v.67, p.1687-1695, 2006. Available from: <https://doi.org/10.2460/ ajvr.67.10.1687>. Accessed: Jun. 24, 2019. doi: 10.2460/ ajvr.67.10.1687

RAFAEL, L. A. Farmacocinética da gentamicina em equinos: estudo comparativo das concentrações em plasma e em líquido sinovial na administração intravenosa ou intravenosa regional. Tese de doutorado, Universidade Estadual Paulista, Botucatu. 2015. 84p.

RUBIO-MARTÍNEZ, L. M.; CRUZ A. M. Antimicrobial regional limb perfusion in horses. Journal of American Veterinary Medical Association. v.228, p.706-712, 2006. Available from: $<$ https://doi.org/10.2460/javma.228.5.706>. Accessed: Jun. 24, 2019. doi: $10.2460 /$ javma.228.5.706

RUBIO-MARTÍNEZ, L. M. et al. Clinical use of antimicrobial regional limb perfusion in horses: 174 cases (1999-2009). Journal of American Veterinary Medical Association, v.241, p.1650-1658, 2012. Avaiable from: <https://doi.org/10.2460/ javma.241.12.1650>. Accessed: Feb. 19, 2020. doi: 10.2460/ javma.241.12.1650.

SANTSCHI, E. M. et al. How to perform equine intravenous digital perfusion. 44th Annual Convention of the American Association of Equine Practitioners. Baltimore, Maryland, p.198-201. 1998. Available from: <https://pdfs.semanticscholar.org/5279/ f585e1363a02b2c27ac2e40d081775b15d52.pdf>. Accessed: Jun. 24, 2019.

SCHEUCH, B. C. et al. Comparison of intraosseous or intravenous infusion for delivery of amikacin sulfate to the tibiotarsal joint of horses. American Journal of Veterinary Research. v.63, p.374-380, 2002. Available from: <https://doi.org/10.2460/ ajvr.2002.63.374>. Accessed: Jun. 24, 2019. doi: 10.2460/ ajvr.2002.63.374.

SKOPNIK, H. et al. Pharmacokinetics and antibacterial activity of daily gentamicin. Archives of Diseases in Childhood. p.67, p.57-61, 1992. Available from: <http://dx.doi.org/10.1136/ adc.67.1_Spec_No.57>. Accessed: Jun. 24, 2019. doi: 10.1136/ adc.67.1_spec_no.57.

WERNER, L. A. et al. Bone gentamicin concentration after intraarticular injection or regional intravenous perfusion in the horse. Veterinary Surgery. v.32, p.559-565, 2003. Available from: $<$ https://doi.org/10.1111/j.1532-950X.2003.00559.x>. Accessed: Feb. 19, 2020. doi: 10.1111/j.1532-950x.2003.00559.x.

WHITEHAIR, K. J. et al. Regional limb perfusion with antibiotics in three horses. Veterinary Surgery. v.21, p.286-292, 1992a. Available from: <https://doi.org/10.1111/j.1532-950X.1992. tb00066.x>. Accessed: Jun. 24, 2019. doi: 10.1111/j.1532950X.1992.tb00066.x

WHITEHAIR, K. J. et al. Regional limb perfusion for antibiotic treatment of experimentally induced septic arthritis. Veterinary Surgery. v.21, p.367-373, 1992b. Available from: <https://doi. org/10.1111/j.1532-950X.1992.tb01713.x>. Accessed: Feb. 19, 2020. doi: 10.1111/j.1532-950x.1992.tb01713.x. 